\title{
Park Structures as Determinant of Bird Species Diversity in Putrajaya
}

\author{
Hazlinda Abd Aziz¹, Mohd Hisyam Rasidi2 \\ 1 Doctoral Candidate, Faculty of Built Environment, Universiti Teknologi Malaysia, Skudai, Johor Malaysia \\ 2 Senior Lecturer, Faculty of Built Environment, University Teknologi Malaysia, Skudai Johor Malaysia \\ *hazlinda.aziz@gmail.com
}

\begin{abstract}
The presence of birds is important to verify ecological condition in cities since they respond well to the availability of habitat structure. This study aims at investigating park structures which influence bird species diversity in Putrajaya. The studied areas consist of six metropolitan parks. Vegetation structure and bird species data were collected through distance sampling method. Evaluations of overall 12 points were carried out to be mapped in the Standard Computer-aided Design (CAD) software. The results reveal that park with higher density vegetation supports higher habitat variables including food, foraging substrate and nesting site for birds to survive in Putrajaya.

Keywords: Vegetation structure, Bird diversity, Ecological guilds, Putrajaya

eISSN 2514-751X @ $\odot$ 2018. The Authors. Published for AMER ABRA cE-Bs by e-International Publishing House, Ltd., UK. This is an open-access article under the CC BY-NC-ND license (http://creativecommons.org/licenses/bync-nd/4.0/). Peer-review under responsibility of AMER (Association of Malaysian Environment-Behaviour Researchers), ABRA (Association of Behavioural Researchers on Asians) and CE-Bs (Centre for EnvironmentBehaviour Studies), Faculty of Architecture, Planning \& Surveying, Universiti Teknologi MARA, Malaysia.

DOI: https://doi.org/10.21834/aje-bs.v5i17.47
\end{abstract}




\subsection{Introduction}

Parks are different to each other as each park have different function that demonstrate different physical character. Physical characters including vegetation distribution pattern, density and canopy coverage are some factors that influence park performance which is important for bird species habitants in cities. Hence, this study aimed at investigating species distribution and abundance of birds which were influenced by vegetation structure of the parks. The bird diversity and abundance were differentiate based on ecological guilds including primary food habit, foraging substrate and nesting habit. The correlation between birds abundance and vegetation structures were verified through evaluation of the ecological guilds listed in this study. The study would finally consider how the vegetation structures relate to the abundance and distribution of bird species in Putrajaya. Finally, this paper hypothesised that park with complex vegetation structures would promote higher level of inhabitants for bird species.

\subsection{Literature Review}

\subsection{Importance of Parks in Urbanized Area}

The result of two factors which is natural increase in population and migration to urban areas are the urbanization process that increase propotion of an entire population lives in a city. In Malaysia, the urbanization process is expanding rapidly (Tarmiji et.al, 2012) due to high demand of residential, business and industrial development. The high development process have extremely impacts on the limited green spaces in city area. Hence, the process of fragmentation alter and give big changes on physical surface of the land (Sham Sani, 1984). Hence, urban green spaces such parks, garden and green corridor play a vital role in stabilizing ecosystem function within city areas. The urban green spaces are represented by various types consists of (1) natural landscape which also called as remnant patches of original ecosystem (Forman and Godron 1986 and Abdullah et al. 2006) such as forests, riparian zone, etc.; (2) human landscape which been created and managed by man (Tamara and Eva 2004 and Abdullah et al. 2006) such as parks, street landscape, gardens, greenways, etc.; and (3) areas where natural succession occurs due to the absence of direct human influence (Tamara and Eva 2004) such as abandoned courtyards, areas of destroyed buildings, etc. (Forman and Godron, 1986). However, among all the urban green spaces listed, park which is categorized as human landscape begin to be recognized as conservation land in the urban areas. Thus, park areas need to be preserved as it serves good ecological functions towards city area as a whole (Tamara and Eva, 2014). Furthermore, parks can be seen as influential factors of biodiversity richness as they offer diversity by adding to the complexity, patterns, richness and intricacy of biotic community (Mazlina et al. 2010). Up to that point, urban green space planning in Malaysia develops basic requirement which necessitate at least ten percent of open space to be integrated in all urban development including residential, commercial, institutional and industrial area (Department of Town and Regional Planning, 2006). In accordance with the planning requirement, Putrajaya has developed their own standard parks typology primarily divided based on its size hierarchy 
Abd Aziz, H., \& Rasidi, M.H. / Asian Journal of Environment-Behaviour Studies (ajE-Bs), 3(9) Jul / Aug 2018 (p.115-124)

(Table 1).

Table 1: Hierarchy and distribution of open space for Putrajaya-Land Use Class III (Perbadanan Putrajaya)

\begin{tabular}{llcc}
\hline & Open Space Category & Area (Hectares) & Percentage \\
\hline 1. & Metropolitan park & 667.22 & 34.55 \\
2. & Urban park & 166.81 & 8.64 \\
3. & Local park & 116.74 & 6.05 \\
4. & Neighbourhood park & 21.69 & 1.12 \\
$\mathbf{5 .}$ & Playground & 5.30 & 0.27 \\
$\mathbf{6 .}$ & Green Connector & 267.22 & 13.84 \\
7. & Buffer zone & 112.64 & 5.83 \\
8. & Water bodies & 573.03 & 29.68 \\
& TOTAL & 1930.43 & 100.00 \\
\hline
\end{tabular}

\subsection{Relationship Between Park Structure and Bird Species diversity}

Diversity of birds in the development of urban park areas must have strong correlation to the level of vegetation diversity. Inhabitants level of park to birds usually influenced by habitat variables including vegetation density and diversity, the abundance and age of trees, the amount of native vegetation, presence of waterbodies and the level of human disturbance (Jokimaki 1999 and Fernandez Juricic 2004). Furthermore, the tree structure and composition is usually associated with the abundance and diversity of wildlife species as it provides essential shelter and food resources (Diaz et.al, 2005 and Hagar, 2007) which creates comfort and secure for wildlife. Scientists estimated that approximately 60-90 percent of life is found in the trees as they receive food and nesting site from the foliage, cavity, bark and branch. Referring to Bartemucci (2006) in his paper stated that there would be less diversity in understory plant species if the nurse log was exposed to a higher level of light and a lower canopy density because these plants usually live on the forest floor where they are shaded by the tall surrounding trees. Understory vegetation like small trees, shrubs and undergrowth are also important in supporting wildlife species and ecosystem services (Tuanmu et.al, 2010) especially for Malaysian birds which are not strong fliers and spend much time at or near ground level. Inasmuch, basic habitat requirements of park is diverse plant species, diverse low vegetation and dense vegetation. Thus, bird species abundance would increase along with the increasing of vegetation diversity.

However, the performance of parks to bird species diversity would be based on other influential factors like the park function because different types of parks may have different physical character. Logically, parks that serve ecological functions would have better numbers of bird inhabitants as this types of park usually have much complex, dense and diverse vegetation types. Thus, it is believed that type and function of parks also have significance value towards bird species diversity. 


\subsection{Methodology}

\subsection{Site Selection}

Putrajaya is a city with $38 \%$ of the area has been set aside as green areas. Putrajaya was well-known as an estate land primarily consists of oil palm plantations. Hence, all green spaces occured now can be categorized as human created landscape which were designed and planned properly. In total, Putrajaya consists of eight types of open spaces but the sites used in the survey were all public access sites consists of only six Metropolitan Park within Putrajaya area (figure 1) including Taman wetland, Taman Botani, Taman Wawasan, Taman Putra Perdana and Taman Warisan Pertanian. The selected parks were within $5 \mathrm{~km} \times 5 \mathrm{~km}$ in distance located at the centre of Putrajaya. First part of the survey was done early September of 2012 followed by the second part on June 2014.

The six parks were categorized based on its function; conservation and recreational (table 2). Besides, size of each parks were also tabulated in the table to give initial ideas on park characteristics. Three out of six parks including Taman Wawasan, Taman Putra Perdana and Taman Pancarona were designed mainly for recreational purposes. The other three which are Taman Wetland, Taman Botani and Taman Warisan Pertanian were designed for conservation purposes.

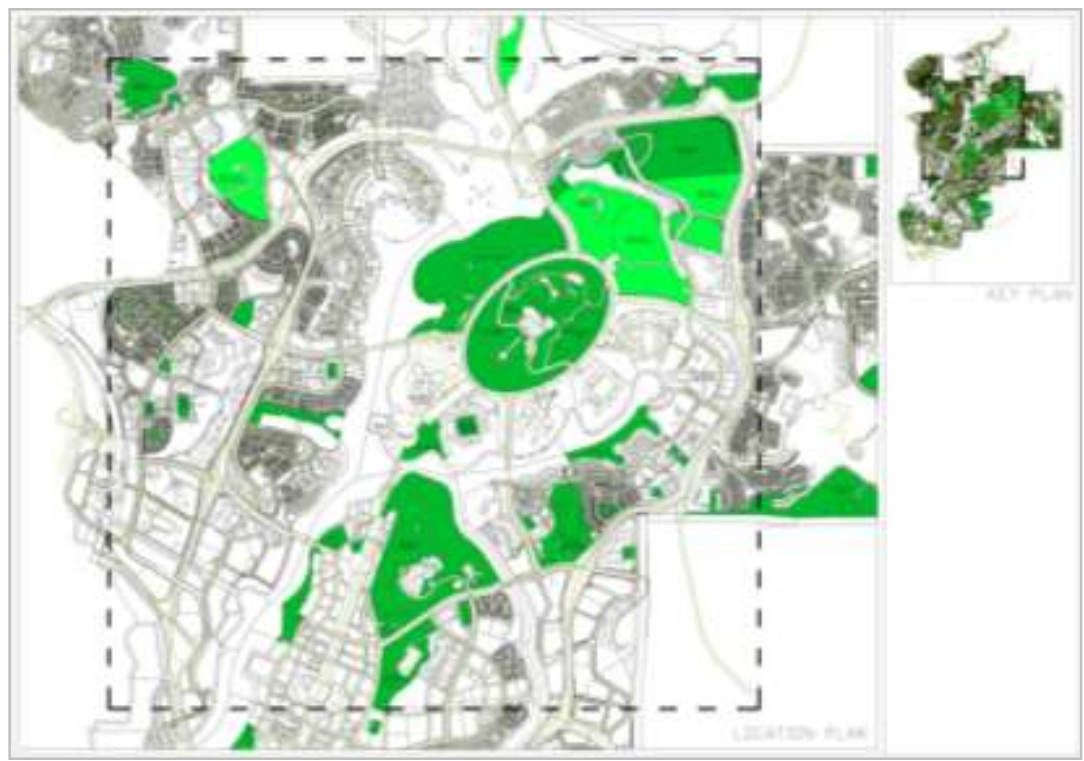

Figure 1: The study are selected was within $5 \mathrm{~km} \times 5 \mathrm{~km}$ in distance (includes six parks) 
Table 2: Characteristics and function of the Studied Parks

\begin{tabular}{lll}
\hline Parks & Size (ha) & Function \\
\hline Taman Wetland & 126 & Conservation \\
Taman Botani & 93 & Conservation \\
Taman Wawasan & 137 & Recreational \\
Taman Putra Perdana & 62.4 & Recreational \\
Taman Pancarona & 14.2 & Recreational \\
Taman Warisan Pertanian & 14.6 & Conservation \\
\hline
\end{tabular}

\subsection{Data Collection}

Two observers were assigned for data collection which one person recorded habitat variables including vegetation height, vegetation types and vegetation arrangement while the other one person recorded birds existence including individual species and perched site. Observers were assigned to assess two points for each park areas. During a count, an observer stand in a point of 50 meter radius and recorded all birds seen and heard for 15 minutes. Judgement of distance was aided with the use of a rangefinder. All counts were conducted early in the morning between 7:00 and 10:00 hour and before late evening between 4:00 and 7:00 hour on days without rain. Time selected for the observation were early in the morning and late evening because birds are active during that hours.

\subsection{Analysis}

Bird counts were classified into broad categories based on the primary food habit, foraging substrate and nesting habit requirements. For each ecological guilds, a species could only be assigned to one category. The observation recognised seven dietry guilds: granivore, frugivore, nectarivore, insectivore, insectivore-Complex, omnivore and carnivore. Granivores were birds that took mainly seeds. Frugivores were birds that fed on fruits. Nectarivores nectar feeders. Insectivores were birds that fed on insects and small anthropods while insectivores-complex were birds that took not only insects but also fruits or seeds or nectar. Omnivores generally eat animal and plant material such as non-insects and fruits. Carnivores the active hunter ate everything from fish, rodents and other small birds as their primary food habits.

Foraging substrate refers to the perched site like bark, ground, lower foliage, upper foliage, air and water elements. While for nesting requirements refer to the nature of nesting site of bird species and were categorized based on the following categories: ground nesters, undergrowth or shrub nesters, tree nesters, cavity nesters, building nester and brood parasite. Information on dietry, foraging substrate and nesting habits were gathered from published literature (Wells, 1999 and Robson, 2000) and through site observations.

On the other hand, 10 meter $\times 10$ meter lines was overlapped to the Google Earth image of each parks to evaluate the green coverage (figure 2). Areas with green coverage were hatched using green colour while the red line in the map indicate park boundary. As for the 
Abd Aziz, H., \& Rasidi, M.H. / Asian Journal of Environment-Behaviour Studies (ajE-Bs), 3(9) Jul / Aug 2018 (p.115-124)

other habitat variables like vegetation height, vegetation types and vegetation arrangement were then correlate to the bird species to see how birds react to the surrounding landscapes
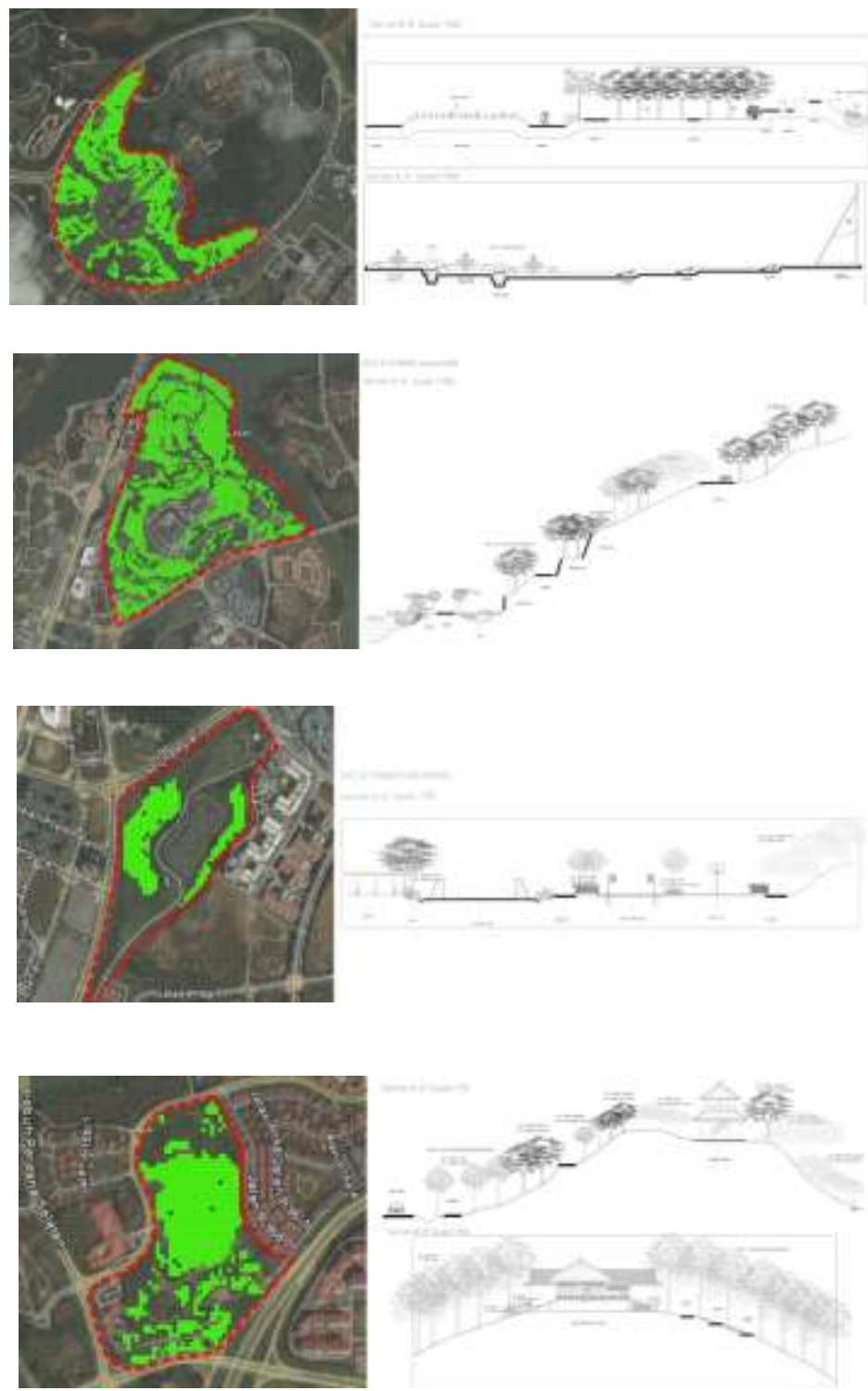

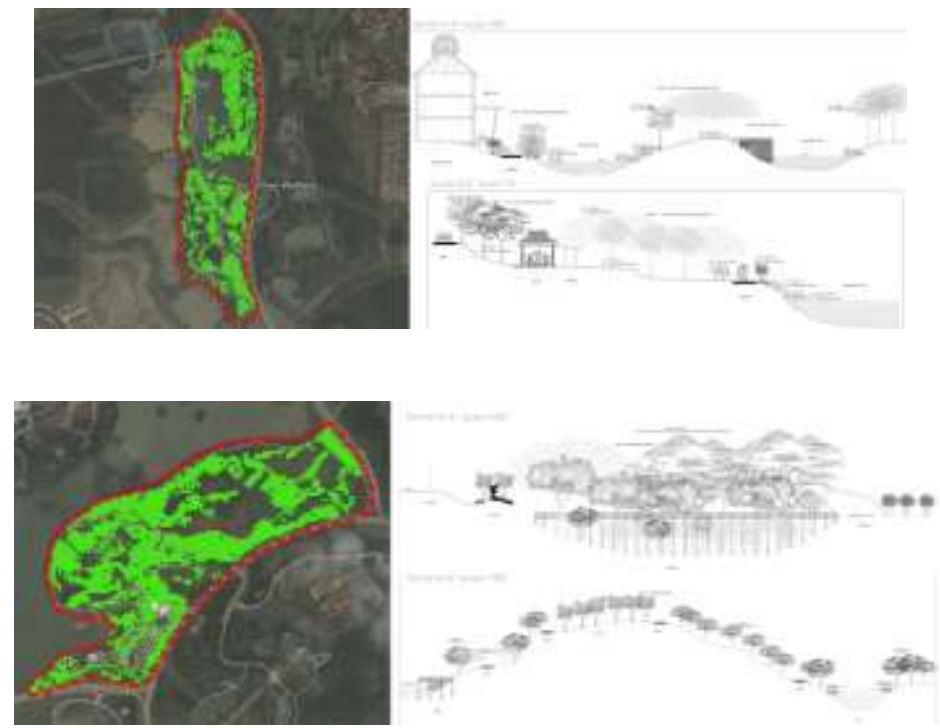

Figure 2: Planting Distribution Pattern in each parks from top to the bottom: Taman Putra Perdana; Taman Wawasan; Taman Pancarona; Taman Warisan Pertanian; Taman Wetland and Taman Botani

\subsection{Result And Discussion}

The data collected from each physical character of the parks observation, originally sketch by hand, was later translated into digital form. This information was supported by site images which captured during the field survey. The data from observation sheet were coded into Microsoft Excel Software for descriptive statistical analysis. The bird data were also been coded into Microsoft Excel Software to count their total abundance according to the selected ecological guilds in the study. The main focused of these analyses were to understand how park structures relate to bird abundance and diversity. The additional attributes such as park size and function details were also considered in giving additional information of the relationship.

\subsection{Habitat Variables and Bird Counts}

Descriptive analysis in Table 3 gave an overview on the character of vegetation found on site and total bird count for each studied parks. The empirical findings about park performance were discussed on the basis of differentiating between habitat variables measured including primary vegetation types and vegetation height which has strong relation towards the food and nesting availability for birds to survive. In addition, species total in the table descriptively explained the species richness of birds in each park. Thus, the highest species richness among the six studied parks was Taman wetland which recorded 224 individual total individual species belonging to 17 bird species. Taman Botani which have the same average 
of tree height reported second highest of species richness calculation which is 13 in overall. Taman Wawasan which predominantly consists of forest trees range from 10 to 15 meters in height recorded the lowest species richness which is 11 . While for the other three parks showed the same total of species richness but varied in individual bird total. Overall, the findings of the study indicate that species richness of birds is high among park with larger in size, higher green coverage, serve ecological functions and inhabits higher vegetation height

Table 3: Descriptive findings of habitat variables and total bird count at each park areas

\begin{tabular}{|l|c|c|c|c|c|}
\hline \multirow{2}{*}{ Parks } & \multicolumn{3}{|c|}{ Habitat Variables } & \multicolumn{2}{c|}{ Bird Count } \\
\cline { 2 - 6 } & $\begin{array}{c}\text { Primary } \\
\text { Vegetation } \\
\text { types }\end{array}$ & $\begin{array}{c}\text { Vegetation } \\
\text { Height }(\mathrm{m})\end{array}$ & $\begin{array}{c}\text { Green } \\
\text { coverage } \\
(\%)\end{array}$ & $\begin{array}{c}\text { Individual } \\
\text { Total }\end{array}$ & $\begin{array}{c}\text { Specie } \\
\text { s Total }\end{array}$ \\
\hline Taman Wetland (TW), (E) & Wetland Trees & $10-15 \mathrm{~m}$ & 80 & 224 & 17 \\
\hline Taman Botani (TB) (E) & Botany Trees & $10-15 \mathrm{~m}$ & 80 & 153 & 13 \\
\hline Taman Wawasan (TWW) (R) & Forest Trees & $10-15 \mathrm{~m}$ & 80 & 209 & 11 \\
\hline $\begin{array}{l}\text { Taman Putra Perdana (TPP) } \\
\text { (R) }\end{array}$ & Aesthetic Trees & $5-10 \mathrm{~m}$ & 80 & 183 & 12 \\
\hline Taman Pancarona (TP) (R) & Aesthetic Trees & $0-5 \mathrm{~m}$ & 40 & 140 & 12 \\
\hline $\begin{array}{l}\text { Taman Warisan Pertanian } \\
\text { (TWP) (A) }\end{array}$ & Fruit Trees & $5-10 \mathrm{~m}$ & 70 & 92 & 12 \\
\hline
\end{tabular}

\subsection{Ecological Guild Richness}

The results revealed that most of the species found in Putrajaya were carnivores which predominantly eat fish (table 4). The findings indicate that the wetland ecosystem in Putrajaya function well as it successful in providing food materials for bird species including Great Egret, Little Egret, Black-crowned Night Heron, Purple Heron, Grey Heron, Kingfisher and Painted Stork. Frugivorous bird category was ranked at the second level after carnivorous species with total of six species found within studied parks. Accordingly, Putrajaya consists of a fruit conservation park (Taman Warisan Pertanian) which portrays its vegetation types that could support fruit eater birds to survive in Putrajaya city. The species richness reported to be third highest were granivores and insectivores which both recorded four species found. Generally, granivores and insectivores bird species can be found perched on ground to search for seeds and insects.

As for the foraging substrate, ground, lower foliage or branch and water elements were identified to be the most visited sites among bird species. This may be related to the character of Malaysian birds that are not strong fliers and usually spend much time at ground level. On the other hand, most required nesting site among bird species in Putrajaya was tree. Inasmuch, the result was a proven that many bird species require tree not only for foraging but also to build nest. The tree nesting guild is more adapted to urbanisation probably because its nest site are more readily available and their nests are better protected from disturbances due to the tall height of trees. 
Abd Aziz, H., \& Rasidi, M.H. / Asian Journal of Environment-Behaviour Studies (ajE-Bs), 3(9) Jul / Aug 2018 (p.115-124)

Table 4: Descriptive findings of habitat variables and total bird count at each park areas

\begin{tabular}{|c|c|c|}
\hline & No of Species & Relative Abundance \\
\hline \multicolumn{3}{|l|}{ Primary Diet Habits } \\
\hline Granivore & 4 & 0.034 \\
\hline Frugivore & 6 & 0.065 \\
\hline Nectarivore & 3 & 0.013 \\
\hline Insectivore & 4 & 0.099 \\
\hline Insectivore-Complex & 3 & 0.227 \\
\hline Omnivore & 2 & 0.338 \\
\hline Carnivore & 7 & 0.038 \\
\hline \multicolumn{3}{|l|}{ Foraging Substrate } \\
\hline Bark & 0 & 0 \\
\hline Ground & 7 & 3.554 \\
\hline Lower Foliage/Branch & 7 & 0.159 \\
\hline Upper Foliage/Branch & 6 & 0.067 \\
\hline Air & 2 & 0.098 \\
\hline Water & 7 & 0.038 \\
\hline \multicolumn{3}{|l|}{ Nesting Habits } \\
\hline Ground & 2 & 0.017 \\
\hline Undergrowth/Shrub & 3 & 0.035 \\
\hline Tree & 17 & 0.264 \\
\hline Cavity & 4 & 0.464 \\
\hline Building & 3 & 0.117 \\
\hline Brood Parasite & 0 & 0 \\
\hline
\end{tabular}

\subsection{Conclusion}

The study found that bird community in Putrajaya areas were dominated by carnivores bird species as Putrajaya consists from wide range of wetland areas. The wetland probably offer wetland trees for bird nesting site and aquatic animals like fish for feeding materials. However, when refering to the relative abundance, the most common birds found in Putrajaya areas was omnivores birds. The omnivores diet guild is most adapted to urbanisation probably because the feeding materials from animals and plants can be found easily in city 
areas. Thus, provision of areas of rough grass is likely to increase both insects and noninsects food resources for birds and therefore increase species richness. In overall, this study provides an exploratory look on the responses of bird guilds to the various facets of urbanisation. The presence of more wildlife species to the parks area regardless becasue of comfort and secure factors served.

\section{Acknowledgment}

This research is funded by GUP (Vot $00 \mathrm{H} 65$ ) and Mybrain 15 from the Ministry of Higher Education, Malaysia.

\section{References}

Bertamucci, P., Messier, C., \& Canham, C. D. (2006). "Overstory influences on light attenuation patterns and understory plant community diversity and composition in southern boreal forests of Quebec", Canadian Journal of Forest Research Vol. 36 Issue 9, p. 2065-2079.

Diaz, I. A., Armesto, J. J., Reid, S., Sieving, K. E., \& Willson, M. F. (2005). Linking forest structure and composition: Avian diversity in successional forests of Chiloé Island, Chile. Biological Conservation, 123, 91-101.

Hagar, J. C. (2007). Wildlife species associated with non-coniferous vegetation in Pacific Northwest conifer forests: A review. Forest Ecology and Management, 246, 108-122.

JPBD (2006). National Urbanization Policy. Kula Lumpur: Federal Department of Town and Country Planning, Ministry of Housing and Local Government, Malaysia.

Forman, R.T.T., \& Godron, M. (1986). Landscape Ecology. John Wiley \& Sons, New York.

Mazlina, M., Ismail, S., \& Ismail, M. (2010). Experiantel Contact with Green Infrastructure's Diversity and Well-being of Urban Community. Asian Journal of Environment-Behaviour Studies, 3, 33-47.

Robson, C. (2000). A Field Guide to the Birds of South-East Asia. New Holland Publishers, London.

Saiful Arif, A., \& Nakagoshi, N. (2006). Changes in Landscape Spatial Pattern in the highly Developing State of Selangor, peninsular malaysia. Landscape and Urban planning, 77, 263-275.

Sham, S. (1984). Several Aspects of Climate in Sabah. Enthography of Sabah Volume 8. Universiti Kebangsaan Malaysia, Yayasan Sabah, Bangi.

Tamara, R., \& Eva, P. (2004). Evaluation of Urban Green Spaces in Bratislava. Boreal Environment Research, 9 , 469-477.

Tarmiji, M., Usman, Y., Norizawati, M. A., \& Aimi, S. M. (2012). Population and Spatial Distribution of Urbanisation in Peninsular Malaysia 1957-2000. Malaysia Journal Society and Space 8, 2, $20-29$.

Tuanmu, M., Vina, A., Bearer, S., Xu, W., \& Ouyang, Z. (2010). Mapping Understory Vegetation Using Phenological Characteristics Derived From Remotely Sensed Data. Remote Sensing of Environment, 114, 1833-1844.

Wells, D.R. (1999). The birds of the Thai-Malay Peninsula. In:Non-Passerines, vol. 1. Academic Press, San Diego. 